Vol. 18 (2009): 283-301.

\title{
Productivity growth on Finnish grain farms from 1976-2006: a parametric approach
}

\author{
Sami Myyrä ${ }^{1}$, Pekka Pihamaa ${ }^{2}$ and Timo Sipiläinen ${ }^{1}$ \\ ${ }^{1}$ MTT Agrifood Research Finland, Economic Research, Luutnantintie 13, FI-00410 Helsinki, Finland, \\ ${ }^{2}$ Ministry of Agriculture and Forestry, Finland, \\ ${ }^{1}$ email: firstname.lastname@mtt.fi
}

\begin{abstract}
In the long term, productivity and especially productivity growth are necessary conditions for the survival of farms and the food industry in Finland. The natural handicap and small farm size are challenges, but farmers are further challenged by the decoupling of supports and their transformation into direct income payments. Additionally, farmers' actions are limited by some institutional settings that substantially reduce incentives to improve productivity.

Technical progress was found to drive the increase in productivity on grain farms in Finland. The scale had only a moderate effect and for the whole study period (1976-2006) the effect was close to zero. Total factor productivity (TFP) increased, depending on the model, by $0.6-1.7 \%$ per year. The results demonstrated that the increase in productivity was hindered by the policy changes introduced in 1995 . The cumulative increase in TFP over the study period was at the same level as the measured yearly changes in TFP. The results highlight the nature of grain farming in Finland as well as the challenges in simultaneously taking into account the general trend and yearly variation in TFP.
\end{abstract}

Key-words: technical change, scale effect, production function, time trend, general index.

\section{Introduction}

Although Finns prefer Finnish food, most Finnish products have to compete on the market with foreign alternatives at a fairly uniform price level. The same price linkage applies to primary production, which provides raw materials for the food industry. Therefore, in the long term, productivity and especially productivity growth are necessary conditions for the survival of farms and the food industry on the market, and in general for the continuation of agriculture in Finland. 


\section{AGRICULTURAL AND FOOD SCIENCE}

\section{Myyrä, S. et al. Productivity growth on Finnish grain farms}

Profitability at the farm level is determined by prices, subsidies and the productivity at which inputs are transformed to outputs. Prices and subsidies are to a large extent exogenous for farmers. However, farmers are able to adjust productivity at the farm level. This takes place according to the incentives given in prices and subsidies. One could say that increased productivity is the farmer's contribution to the future success of Finnish agriculture.

The problem in Finland is that productivity has remained low and productivity growth has stagnated for several reasons. First, productivity has been low because of the natural handicap resulting from the unfavourable climate and the small size of farms. Second, the political tendency of decoupling market-distorting price supports and transforming them into direct income payments has challenged farmers to reach the productivity goals of the CAP under Nordic production conditions. Once support payments are decoupled from production decisions, the economic incentives for productivity improvements diminish if farmers find that production costs will in any case remain higher than marginal returns. Third, farmers' incentives are also limited by some institutional settings that substantially cut incentives to improve productivity. Land tenure insecurity is one of the most important of these institutional questions.

The combination of prices, subsidies and productivity provides tools for agricultural policy. In the case of declining productivity in agriculture, the Finnish government has to put more money into subsidies in order to sustain farm profitability and the running of Finland's primary industry. In the case of increasing productivity, the situation is reversed and becomes attractive for consumers and taxpayers. Productivity analysis is needed both to provide information about current productivity trends in agriculture and to guide policy makers when they decide on the most appropriate policy measures. This gives justification for the present study.

Finnish agriculture has experienced a rapid structural change within the last thirty years. The number of active farms in 1976 was 242 682, while in 2006 it had declined to only 69071 (TIKE
2006). This indicates an average annual exit rate as high as $4.1 \%$. However, the number of grain farms has not decreased in conformity with the general trend, as from 1990 to 2006 the annual decrease was only 1.3\%. Under EU membership the number of grain farms has fallen even less, by $0.27 \%$ annually, as many small- and medium-sized farms have ceased animal production but continued crop farming. Simultaneously, this transformation has often included moving to other occupations and to part-time farming. The relatively slow structural change in grain farming may have slowed down the rate of productivity growth at the sector level.

The slow structural development in grain farming as compared to other production lines is probably a consequence of several policy measures implemented during the period from 1976 to 2006. Finnish agricultural policy has faced numerous urgent tasks in maintaining sufficient farm income. Within the period from 1976 to 1994, these tasks involved a variety of outcomes with respect to the objective of self-sufficiency in grain production. High output prices and good yields led to strong overproduction in 1976 and 1977. For example, wheat production exceeded domestic consumption by $50 \%$. With policy measures including compulsory set-aside and export duties on grain, self-sufficiency collapsed from 1978-1982 to an average level of $50 \%$ of total consumption. Since then, selfsufficiency in grains has remained between $75 \%$ and $125 \%$, except in some years with extremely poor weather conditions.

The policy reform caused by Finland's entry into the EU in 1995 significantly reduced agricultural output prices. To counterbalance the effects of the price decrease, extensive policy measures were introduced with the objective of maintaining farm income through income support ${ }^{1}$ (per hectare and per animal payments) and policy measures such as investment aids that were expected to support pro-

1 The Finnish agricultural subsidy system has four components: the arable area payment under the Common Agricultural Policy (CAP), Less Favorable Area (LFA) support, environmental support, and national aid and northern aid for agriculture. The subsidy system is complicated. In addition, the conditions for crop production and the subsidy system differ between southern and northern Finland (Niemi and Ahlstedt 2004). 
Vol. 18 (2009): 283-301.

ductivity growth and structural development. Despite the new policy measures, the marginal value product (MVP) of both short- and long-term land improvements ${ }^{2}$ significantly decreased with the reform. If we assume increasing returns to scale, the reduced use of inputs is expected to depress the average product (i.e. productivity) of inputs (see e.g. Gravelle and Rees 1998, p. 186). On the other hand, a previous index-based productivity study suggested that over the long term the reduction in MVP has delayed land improvement, which is likely to slow down productivity growth especially on grain farms (Myyrä 2004).

For example, the soils of Finland have been formed from acidic rock and the $\mathrm{pH}$ values in agricultural soils of the country are commonly low. Therefore, liming is one of the basic ameliorative measures used to maintain good yields. A slight but steady increase in soil $\mathrm{pH}$ could be observed from the 1960s until the 1990s, but during the last decade in particular this progress has stopped because of reduced liming.

Institutions also have an influence on farmers' incentives for productivity improvements. Despite the rapid decline in the number of active farmers, the number of farmland owners has not decreased at a similar rate, since many former farmers and their successors have kept the land in their ownership but leased it out to active farmers. Farming under the insecurity of land tenure caused by land leasing in strongly regulated ${ }^{3}$ land lease markets has, however, led to the neglect of land improvements. As land improvements are a necessary condition for improving productivity in grain farming, this neglect may also have a long term influence on productivity growth. In addition to land improvements, land consolidation and restructuring of field

2 Fertilization is an example of a short-term land improvement measure, while long-term land improvement measures include liming and investments in drainage systems.

3 The standard land lease contract in Finland is a short-term contract with a fixed duration and a fixed cash lease payment per year. About $40 \%$ of all lease contracts have a duration of five years. With only a few exceptions, the annual cash lease payment is fixed per hectare of land when the contract is signed. plots is especially needed under rapid structural development.

Weather conditions are the main driver of interannual variability in productivity on Finnish grain farms. This is because most of the inputs are applied in the spring on the basis of expected yields, but the output is strongly affected by the weather conditions during the growing season. Liu and Pietola (2005) showed that yield volatility is large and dominates price volatility in Finnish wheat production. Nauges et al. (2009) reported that between 1995 and 2003, the yield explained 80\% of the variation in annual wheat revenues, while the price explained $18 \%$ and the acreage only $2 \%$. Thus, large variation in productivity growth in sequential periods typically occurs in Finnish data. This feature of the data challenges the methods of analysis: they should reveal the variation but still capture the long-term trends in productivity growth.

This study has three main goals. The first goal is to determine the rate of productivity growth on Finnish grain farms over the 30-year period from 1976 to 2006. We apply both time trend and general index techniques in order to capture the patterns of technical change during the period. The second goal is to examine how technical change has evolved in different subsidy regions and in different size classes of grain farms. The third goal is to clarify the role of the scale effect in productivity growth in general and especially in various farm size classes, but also in different subsidy regions.

In earlier Finnish studies on productivity change, both econometric estimation (Hemilä 1982, Ylätalo 1987, Ryhänen 1994, Sipiläinen and Ryhänen 2005, Sipiläinen 2007) and index numbers (Ihamuotila 1972, Sims 1994, Myyrä and Pietola 1999) have been applied. The majority of these studies are relatively old, and even fewer have separately examined grain production. The two exceptions in this respect are a study by Myyrä and Pietola (1999), in which the data covered almost the entire 1990s and index number techniques were applied, and Sipiläinen's (2003) examination of productivity growth on cereal farms, applying nonparametric methods (data envelopment analysis, DEA) and the Malmquist index. In the latter study, productivity 


\section{AGRICULTURAL AND FOOD SCIENCE}

\section{Myyrä, S. et al. Productivity growth on Finnish grain farms}

growth from 1989 to 2000 was decomposed into technical change and technical efficiency change. The results suggested relatively moderate technical change and only a minor change in technical efficiency. The same conclusion concerning the change in technical efficiency also applies to dairy farms (Sipiläinen 2008). Therefore, we concentrate in this article on technical change and on the scale component of productivity change.

Returns to scale (RTS) are of particular interest in Finland, where the goals of the government include improvement in the productivity and profitability of production. If returns to scale are increasing, productivity can be increased by enlarging the scale of production. Conversely, if returns to scale are decreasing, productivity can be increased by shrinking the scale.

Our study is carried out at the farm level. If returns to scale are increasing, structural change and the growth in scale should still continue because this would support productivity growth. Decreasing RTS should probably also not imply an immediate reduction in the scale of production, since even if we could improve average productivity by shrinking the scale this would not necessarily be profitable in economic terms.

Technical change (TC) is usually the most important component of productivity improvement. Technical change means either a neutral or non-neutral shift in the production function over a period of years. Such a shift is the result of introducing new and more productive technology. This technical change effect has to be taken into account, especially in long-term analysis (Kumbhakar and Lovell 2000, p. 107). In this study we apply a flexible functional form, which allows nonneutral technical change and non-constant returns to scale. Our model also allows heterogeneity of technical change between size classes of farms. In addition, we apply both time trend and general index methods in order to capture the long- and short-term variation in technical change.

The results show that average returns to scale are less than 1 in all models that apply farm-specific intercepts (fixed effect). This suggests that on average, no productivity gains can be obtained by increasing the scale of production. Productiv- ity mainly grows because of technical progress, which averages $1.7 \%$ per year in the time trend (TT) model and $0.8 \%$ per year in the general index (GI) model and is most rapid in the largest farm classes and in the south of Finland.

The paper is structured as follows. In the next section the econometric model is derived. Section three presents the Finnish grain farm data and the variables used in the analysis. Section four provides the results and econometric tests and section five the discussion and conclusions.

\section{The econometric model}

\section{Modelling productivity change}

In the case of a logarithmic production function, following Denny et al. (1981) and Bauer (1990), the Divisia index of total factor productivity (TFP) growth can be defined as the growth in scalar output $(y=f(x, t ; \alpha))$, which cannot be explained by the growth in the input quantity index (vector $\mathrm{X}$ ) over time $(\mathrm{t})$ :

$\dot{T F P}=\dot{y}-\dot{X}$ when $\dot{X}=\sum_{j} \frac{w_{j} X_{j}}{C} \dot{X}_{j}$,

where $\frac{w_{j} X_{j}}{C}$ is the observed cost share on the input $j$ ( $\mathrm{w}$ is the price of the input $\mathrm{x}$ ) and the dot indicates the rate of change. In a single output case, with constant returns to scale (CRS) and cost efficiency (CE), TFP growth equals technical change (TC). In our analysis, we assume efficiency but allow non-constant returns to scale. Thus, our production function is not a frontier function but an average production function, and technical change is measured in relation to the shifts in this average function.

Taking the total differential of logarithmic $y=f$ $(\mathrm{x}, \mathrm{t} ;)$ and adding it into (1) we obtain:

$$
\begin{gathered}
\operatorname{Tr} \dot{P}=\partial \ln \mathrm{y} / \partial \mathrm{t}+\sum_{\mathrm{j}}\left(\varepsilon_{\mathrm{j}}-\frac{\mathrm{w}_{\mathrm{j}} \mathrm{x}_{\mathrm{j}}}{\mathrm{C}}\right) \dot{\mathrm{x}}_{\mathrm{j}} \\
=\partial \ln \mathrm{y} / \partial \mathrm{t}+\left(\sum_{\mathrm{j}} \varepsilon_{\mathrm{j}}-1\right) \sum_{\mathrm{j}}\left(\frac{\varepsilon_{\mathrm{j}}}{\sum_{\mathrm{j}} \varepsilon_{\mathrm{j}}}\right) \dot{\mathrm{x}}_{\mathrm{j}}+\sum_{\mathrm{j}}\left[\left(\frac{\varepsilon_{\mathrm{j}}}{\sum_{\mathrm{j}} \varepsilon_{\mathrm{j}}}\right)-\frac{\mathrm{w}_{\mathrm{j}} \mathrm{x}_{\mathrm{j}}}{\mathrm{C}}\right] \dot{\mathrm{x}}_{\mathrm{j}}
\end{gathered}
$$


Vol. 18 (2009): 283-301.

where $\varepsilon_{j}$ is the elasticity of the output with respect to input j, i.e. $\varepsilon_{j}=\partial f(x, t, \alpha) / \partial \ln x_{j}$, when a logarithmic function is $\sum_{j} \varepsilon_{j}$ applied is the sum of output elasticities of inputs, indicating returns to scale. When the sum is larger than one, returns to scale are increasing. A sum of one indicates constant returns to scale, and a sum less than one suggests that returns to scale are decreasing.

If we assume allocative efficiency of production, ${ }^{4}$ we may drop the last part of equation 2 , since the elasticity share and cost share must coincide. From this it follows that we only have two components left that can be derived from the production function: technical change and the scale effect on productivity growth. If production technology is time-invariant, no technical change occurs $(\partial \ln y / \partial t=0)$. On the other hand, if CRS prevails, the scale component does not contribute to productivity growth (see Kumbhakar and Lovell 2000). For this technical decomposition, no detailed price information is needed, although we often have to assume that farmers face equal prices in order to be able to estimate changes in TFP. ${ }^{5}$ The main challenge is thus to estimate a suitable production function.

The main advantage of the parametric approach is that TFP growth can be easily decomposed into sub-components such as technical change and farm-specific returns to scale. The respective decompositions can also be based on non-parametric estimation methods, such as data envelopment analysis, which are less restrictive with respect to assumptions about the production technology, but which usually do not take into account the stochastic nature of the production process.

\section{Time trend and general index models}

In our analysis, we apply two different models to capture technical change. In the time trend model (TT), the trend variable is used as a regressor along

4 We do not necessarily assume technically efficient production. The minimum assumption of our analysis is that technical inefficiency, if it occurs, must be time invariant.

5 Many of the inputs are only recorded in monetary terms. Farm-specific input prices are not available. Thus, sector level price indices have to be applied for the derivation of implicit quantities. with the input variables. It is a proxy variable representing the rate of technical change or the shift in the production function over time, and produces smooth technological changes. As a starting point, we allow a flexible translog functional form with non-neutral technical change and heterogeneous changes between size classes of farms. ${ }^{6}$ The time trend (TT1) model can be written as:

$$
\begin{aligned}
& \ln y=\alpha_{0}+\sum_{j} \alpha_{j} \ln x_{j}+\alpha_{t} t+1 / 2 \sum_{j} \sum_{k} \alpha_{j k} \ln x_{j} \ln x_{k} \\
& +1 / 2 \alpha_{t t} t^{2}+\sum_{j} \alpha_{j t} \ln x_{j} t+v
\end{aligned}
$$

where $\mathrm{v}$ is the random noise term. The production function above is assumed to satisfy symmetry conditions; the regularity conditions can be tested.

The price of smoothness in the measures of technical change in the TT model is that cyclical phenomena and short-term changes in productivity or its components could not be revealed. This feature of the TT model is referred to as the "timetrend straitjacket” in Kumbhakar et al. (1999)

In the general index model of Baltagi and Griffin (1988), the trend variable $t$ is replaced by a vector of dummy time variables, where $\mathrm{A}(\mathrm{t})(\mathrm{t}=$ $1, \ldots, \mathrm{T})$ are parameters to be estimated. The time trend model results in a smooth shift in the production function over time, while time dummies capture erratic changes over time. The latter model is thus less restrictive and preferable when capturing the variation in grain production in Finland. The yields are quite volatile, due to the climatic conditions. In this case we also allow non-neutral technical change. ${ }^{7}$ Thus, the general index (GI) model of the production function can be written as:

$$
\begin{aligned}
& \ln y=\alpha_{0}+\sum_{j} \alpha_{j} \ln x_{j}+1 / 2 \sum_{j} \sum_{k} \alpha_{j k} \ln x_{j} \ln x_{k} \\
& +\sum_{j} \alpha_{j t} \ln x_{j} t+A(t)+v
\end{aligned}
$$

\footnotetext{
6 This heterogeneity is modelled by allowing different slope parameters on time according to the farm size class.

$7 \quad$ In this case we allow heterogeneity of technical change by introducing separate dummies for the farm size classes.
} 


\section{AGRICULTURAL AND FOOD SCIENCE}

\section{Myyrä, S. et al. Productivity growth on Finnish grain farms}

Technical change (TC) (derivatives with respect to time) in the time trend and general index models can be expressed as:

$$
\mathrm{TC}_{\mathrm{TT1}}=\alpha_{\mathrm{t}}+\alpha_{\mathrm{tt}} \mathrm{t}+\sum_{\mathrm{j}} \alpha_{\mathrm{jt}} \ln \mathrm{x}_{\mathrm{j}}
$$

and

$$
T C_{G I 1}=\left(A_{t}-A_{t-1}\right)+\sum_{j} \alpha_{j t} \ln x_{j}
$$

In the flexible translog production function, technical change is clearly not independent of the point at which it is calculated when continuous $t$ is applied. This leads us to use the geometric mean between $t$ and $t+1$ as follows (Coelli et al. 1998):

$$
\begin{aligned}
& \mathrm{TC}_{\Pi 1+1}^{\mathrm{t} t+1}=\left[\left(1+\left(\alpha_{\mathrm{t}}+\alpha_{\mathrm{tt}} \mathrm{t}+\sum_{\mathrm{j}} \alpha_{j \mathrm{t}} \ln \mathrm{x}_{\mathrm{jt}}\right)\right)\right. \\
& \left.\left(1+\left(\alpha_{\mathrm{t}}+\alpha_{\mathrm{tt}}(\mathrm{t}+1)+\sum_{\mathrm{j}} \alpha_{j \mathrm{t}} \ln \mathrm{x}_{\mathrm{j}(\mathrm{t}+1)}\right)\right)\right]^{1 / 2}-1
\end{aligned}
$$

and

$$
\begin{array}{r}
T_{G T 1}^{t, t+1}=\left(A_{t}-A_{t-1}\right)+\left[\left[\left(1+\sum_{j} \alpha_{j t} \ln x_{j t}\right)\right.\right. \\
\left.\left.\left(1+\sum_{j} \alpha_{j t} \ln x_{j(t+1)}\right)\right]^{1 / 2}-1\right]
\end{array}
$$

There is one restriction in the pure time trend model. With unbalanced panel data it is not clear whether the trend variable for a firm entering in period $\tau(1<\tau<\mathrm{T})$ should start from $\tau$ or be rescaled to start from unity. In empirical application the trend variable starts from the starting year of the research period, which is set as equal to 1 .

As we have shown earlier, TFP growth can be expressed as a sum of technical change and the scale effect

$$
\begin{aligned}
& \text { TFP }=T C+(R T S-1) \sum_{j} \frac{\varepsilon_{j}}{R T S} \dot{x}_{j} \quad \text {, where } \\
& \varepsilon_{j}=\frac{\partial \ln y}{\partial \ln x_{j}}=\alpha_{j}+\alpha_{j j} \ln x_{j}+\sum_{k} \alpha_{j k} \ln x_{k}+\alpha_{j t} t
\end{aligned}
$$

and

$$
\mathrm{RTS}=\sum_{\mathrm{j}} \varepsilon_{\mathrm{j}} .
$$

As in the case of technical change, the effect of returns to scale is not independent of the point at which the outcome is calculated. Therefore, we apply a similar approach to that with technical change and determine the scale effect (SE) by average elasticities for sequential periods as follows:

$$
\begin{aligned}
\mathrm{SE}_{\mathrm{t}, t+1}=\sum_{\mathrm{j}} 0.5[ & \left.\left(\mathrm{RTS}_{\mathrm{t}}-1\right) \frac{\varepsilon_{\mathrm{jt}}}{\mathrm{RTS}}+\left(\mathrm{RTS}_{\mathrm{t}+1}-1\right) \frac{\varepsilon_{\mathrm{jt}+1}}{\mathrm{RTS}_{\mathrm{t}+1}}\right] \\
& \left(\ln \mathrm{x}_{\mathrm{jt}+1}-\ln \mathrm{x}_{\mathrm{jt}}\right)
\end{aligned}
$$

Similarly, TFP growth in the general index model is the expression given in equation 8 when $t$ is replaced by $A(t)$. Note that even if there are no quasifixed variables in the model, TFP growth and technical change measures are not the same unless RTS $=1$, such as in the non-parametric Divisia case.

Kumbhakar et al. (1999) reported a wide variety of extensions to the time trend and general index methods discussed in this paper The extended versions are suitable for studies with more heterogeneous data sets containing, for example, different industries. In our case we have a long time series that includes sharp changes in the operating environment for agriculture. Because a standard TT model could not capture changes of this kind, we introduce and test the significance of a CAP dummy in the interaction with time. We also tested whether it is necessary to estimate separate production functions for different subsidy areas. In addition, we test whether the econometric estimation should rely on the fixed effect or ordinary least squares model. The flexibility of the TT model is also extended by introducing some year dummies to capture exceptionally good or poor weather conditions.

\section{The data}

The data were collected from Finnish bookkeeping farms, which are also included in the EU Farm Accountancy Data Network (FADN) for Finland. 
Vol. 18 (2009): 283-301.

This study focuses on grain farms. ${ }^{8}$ We used the following definition to further classify the farms in the data: over a period of three years an average of at least $65 \%$ of annual agricultural turnover (without subsidies) must have been derived from the sale of small grains (wheat, rye, barley, oats and turnip rape) during the research period (Table 1 ). If the required percentage had been set to be higher, the dataset would have become too small. In many cases, grain production has a larger impact on the economy of farms, because subsidies are mainly paid for grain production, while other income may be derived, for example, from machinery contracting, which is not subsidized. Despite the importance of grain farming to the profitability of the farm, the turnover percentage could not be lowered. This was required because some inputs in grain farms are joint and not separable. Machinery used for faming and contracting is again a good example. It has to be noted that the classification of grain farms has a significant impact on the analysis results. However, sensitivity analysis is not required, since the classification has not changed significantly over time and farms included in the data had a constant portfolio of small grains over the study period.

Our analysis is carried out at the farm level. This means that explanatory variables (labour, capital and annual costs) for the production function are correlated. To reduce the degree of multicollinearity we drop the five smallest and five largest farms ${ }^{9}$ from the data for each year of the study period. By this procedure, correlation between explanatory variables drops from $0.65-0.85$ to $0.56-0.79$. The remaining multicollinearity cannot be avoided if the focus is to be kept at the farm level, although it can be avoided if we change the study to the hectare level. However, as we are especially interested in returns to scale, we cannot impose this constraint,

8 Based on bookkeeping classification of farms, but classified in the FADN as specialist cereals, oilseed and protein crops.

9 There is extensive rotation of dropped farms. The farm size could vary between years within the same farm because of land leasing or land transactions. However, the largest farms tend to be the largest throughout the panel. Two out of the five largest farms in 1976 were dropped every year, but none of the smallest five survived until the last year as a dropped farm. because it means that the RTS is expected to be $1 .{ }^{10}$ Absences of multicollinearity might alter the reliability of estimates in the production function.

Measurement of outputs and inputs is critical in productivity analysis. Outputs are measured in monetary terms. The outputs in this data describe the entire monetary output (without subsidies) of the grain farms. Entire outputs are chosen because in the data it is rather challenging to divide the costs between different outputs. For example, machinery and labour could have been used for custom work. The measurement of outputs on a monetary basis is accepted, because almost the same inputs can be used to produce the outputs (grains and turnip rape). This approach is appropriate because it is not possible to combine different grains in terms of weight, but they can be sold on the same markets. The outputs were corrected for price changes by using producer price indexes (Appendix 1). Outputs per hectare were highest around 1990 (Table 1). Partial productivity, or output per hectare, first followed an increasing and then a decreasing trend. The peak was recorded in 1990, which was the last year under a pure national agricultural policy. Finland submitted its application for EU membership in 1991 and joined the EU in 1995. General statistical sources confirm the above, and average yields per hectare have not increased since the early 1990s (TIKE 2006).

Input use is measured in terms of annual input costs, which include variable costs and overhead, labour and capital costs. Labour is measured in hours, and labour hours include only the labour needed to run the farm and not hours used for investments. Capital includes the value of machinery, buildings, land improvements and agricultural land.

To allow a comparison of input use between years, the annual variable cost, which includes annual overheads, was changed to be measured in fixed terms by using the input price index (Appendix 1). The annual costs varied over the research period (Table 1). Annual expenses increased from the beginning of the research period until the early

10 At the hectare level the scale variable could, for example, be fertilizer use. However, the variation in fertilizer use in real farm data is extremely low. To carry out a hectare level analysis we might need experimental data. 


\section{Myyrä, S. et al. Productivity growth on Finnish grain farms}

1990s and then started to decrease, although average farm size continued to increase.

The capital stock is reported in Table 1. To balance the capital stock against inflation it is corrected using the consumer price index (Appendix 1). The table shows that the capital stock follows the same pattern as the annual cost, increasing at the beginning of the study period and then starting to decrease. There is also wide variation in the capital stock. One explanation for the decline in capital stock since the mid-1980s is that grain farms have mainly grown by renting additional land (Iltanen 1999). The variability in capital stock is caused by variability in the proportion of rented and owned land. Rents are included in the annual variable costs. Because of this fundamental change in capital structure, the partial productivity of capital calculated directly from the data is not informative.

The labour variable includes only the hours spent on day-to-day tasks on the grain farms. Average labour use has continually declined, which might be because of improvements in farm machinery as well as changes in farming practices or crop mixes. Heshmati and Kumbhakar (1994) have shown a strong indication of tax-induced over-mechanization in Swedish farming, which might also be the case in Finland. This could be deduced from the partial productivity index for labour, which is constructed by dividing yearly observations of outputs by yearly observations of labour (Fig. 1).

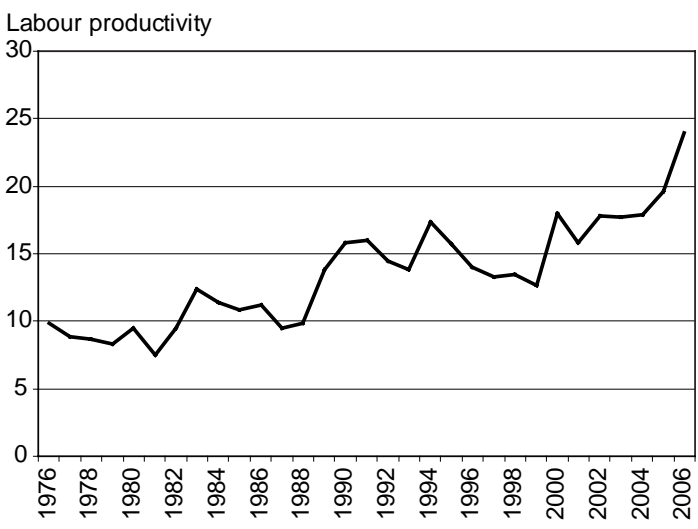

Fig.1. Partial productivity of labour on Finnish grain farms from 1976-2006, calculated as the entire monetary output in 2000 euros and prices (without subsidies) of a grain farm per hour of labour.

The amount of arable land is a good tool to measure the size of a grain farm. The land area of grain farms remained fairly constant from 1976 until the early 1990s. Since then, the land area has been increasing, but the increase has mainly been limited to the largest farms and land leasing.

The data have been divided into five farm size classes according to land area: very large, large, medium, small and very small. Each size class consists of $20 \%$ of the sample in each year. There is a very large rotation in size classes. Only three farms

Table 1. Main statistics at five-year intervals.

\begin{tabular}{|c|c|c|c|c|c|c|c|c|c|c|c|}
\hline \multirow{2}{*}{ Year } & \multicolumn{3}{|c|}{ Hectares } & \multicolumn{2}{|c|}{$\begin{array}{l}\text { Market return } \\
(€ / \text { year })\end{array}$} & \multicolumn{2}{|c|}{$\begin{array}{c}\text { Labour } \\
\text { (hour/year) }\end{array}$} & \multicolumn{2}{|c|}{$\begin{array}{c}\text { Capital } \\
(€ / \text { farm }) \\
\end{array}$} & \multicolumn{2}{|c|}{$\begin{array}{c}\text { Costs } \\
(€ / \text { year })\end{array}$} \\
\hline & $\mathrm{N}$ & Mean & Std & Mean & Std & Mean & Std & Mean & Std & Mean & Std \\
\hline 1976 & 72 & 37.70 & 21.00 & 17901 & 12345 & 1812 & 904 & 213026 & 122206 & 20691 & 13924 \\
\hline 1981 & 86 & 37.25 & 20.69 & 12816 & 8556 & 1700 & 892 & 196329 & 104203 & 18356 & 12231 \\
\hline 1986 & 127 & 36.59 & 19.57 & 16934 & 10969 & 1517 & 792 & 247996 & 153696 & 24273 & 13693 \\
\hline 1991 & 137 & 39.90 & 22.01 & 21536 & 14149 & 1349 & 716 & 230623 & 136985 & 28430 & 17398 \\
\hline 1996 & 85 & 49.57 & 23.59 & 20619 & 11036 & 1473 & 764 & 264937 & 137829 & 25374 & 12007 \\
\hline 2001 & 108 & 52.68 & 31.97 & 20629 & 16412 & 1307 & 799 & 204254 & 132627 & 25032 & 17168 \\
\hline 2006 & 95 & 56.44 & 31.71 & 23855 & 18477 & 996 & 637 & 248869 & 162549 & 24832 & 17116 \\
\hline
\end{tabular}


Vol. 18 (2009): 283-301.

survived from 1976 to 2006 within the same class and only 11 farms remained in the data throughout the time frame of 31 years. Altogether, 405 farms rotated in the data. A more precise picture of the rotation could be captured by taking five-year intervals from the entire time frame. This reveals that "survival" within the same size class does not depend on the initial size class and that there is no change in this over time.

The use of an unbalanced panel in the analysis of productivity growth probably raises the question of selectivity bias and its influence on productivity measures (Olley and Pakes 1996). If less productive farms tend to exit (and/or more productive to enter) the sample, the estimated productivity growth is biased upwards. In our case, there are several factors that may reduce this potential problem. First, the rotation in our data is significant, but it takes place equally in all size groups. Second, entry into the data set is controlled by an economic accounting group at MTT. Entry is voluntary but it is controlled by a selection plan. Third, exit and entry may be caused by a change in the production line. However, there is no evidence that farms with the highest or lowest productivity have changed their production line to or from grain farming.

The different groups have been defined in order to determine whether the development of productivity differs between small and large grain farms. To gain an overview of level differences in different size classes, partial productivities for labour and land are calculated (see Table 2 and 3).

Table 2. Descriptive statistics according to farm size class.

\begin{tabular}{|c|c|c|c|c|c|c|}
\hline $\begin{array}{l}\text { Farm size } \\
\text { class }\end{array}$ & $\mathrm{N}$ & Variable & Mean & Std Dev & $\begin{array}{c}\text { Labour } \\
\text { productivity }^{\mathrm{a}}\end{array}$ & $\begin{array}{c}\text { Land } \\
\text { productivity }^{\mathrm{b}}\end{array}$ \\
\hline \multirow[t]{5}{*}{ very small } & 614 & Market return (€/year) & 6485 & 3227 & & \\
\hline & & Labour (hours/year) & 719 & 443 & 9.02 & \\
\hline & & Capital (€/farm) & 97810 & 39482 & & \\
\hline & & Costs (€/year) & 10813 & 5213 & & 371.01 \\
\hline & & Hectares & 17.48 & 4.28 & & \\
\hline \multirow[t]{5}{*}{ small } & 620 & Market return (€/year) & 11233 & 4602 & & \\
\hline & & Labour (hours/year) & 1153 & 576 & 9.74 & \\
\hline & & Capital (€/farm) & 142829 & 44098 & & \\
\hline & & Costs (€/year) & 15180 & 5253 & & 411.02 \\
\hline & & Hectares & 27.33 & 4.59 & & \\
\hline \multirow[t]{5}{*}{ medium } & 624 & Market return (€/year) & 16266 & 7038 & & \\
\hline & & Labour (hours/year) & 1395 & 621 & 11.66 & \\
\hline & & Capital (€/farm) & 197269 & 51738 & & \\
\hline & & Costs (€/year) & 21652 & 8040 & & 432.50 \\
\hline & & Hectares & 37.61 & 6.13 & & \\
\hline \multirow[t]{5}{*}{ large } & 620 & Market return (€/year) & 23516 & 8681 & & \\
\hline & & Labour (hours/year) & 1668 & 755 & 14.10 & \\
\hline & & Capital (€/farm) & 281043 & 78456 & & \\
\hline & & Costs (€/year) & 28680 & 9752 & & 441.44 \\
\hline & & Hectares & 53.27 & 11.50 & & \\
\hline \multirow[t]{5}{*}{ very large } & 638 & Market return (€/year) & 36939 & 14495 & & \\
\hline & & Labour (hours/year) & 2170 & 853 & 17.03 & \\
\hline & & Capital (€/farm) & 419628 & 133038 & & \\
\hline & & Costs (€/year) & 44398 & 15795 & & 449.48 \\
\hline & & Hectares & 82.18 & 22.83 & & \\
\hline
\end{tabular}

${ }^{\text {a }}$ Market return (€/year) / labour input (hours/year)

${ }^{\mathrm{b}}$ Market return (€/year) / hectares 
Myyrä, S. et al. Productivity growth on Finnish grain farms

Table 3. Descriptive statistics according to subsidy area.

\begin{tabular}{|c|c|c|c|c|c|c|}
\hline $\begin{array}{l}\text { Subsidy } \\
\text { area }\end{array}$ & $\mathrm{N}$ & Variable & Mean & Std Dev & $\begin{array}{c}\text { Labour } \\
\text { productivitya }\end{array}$ & $\begin{array}{c}\text { Land } \\
\text { productivityb }\end{array}$ \\
\hline \multirow[t]{5}{*}{ A } & 1120 & Market return (€/year) & 23388 & 15163 & & \\
\hline & & Labour (hours/year) & 1523 & 820 & 15.36 & \\
\hline & & Capital (€/farm) & 274406 & 154627 & & \\
\hline & & Variable costs ( $€ /$ year) & 29195 & 17055 & & 470.30 \\
\hline & & Hectares & 49.73 & 28.47 & & \\
\hline \multirow[t]{5}{*}{ B } & 1402 & Market return (€/year) & 17259 & 11859 & & \\
\hline & & Labour (hours/year) & 1453 & 867 & 11.88 & \\
\hline & & Capital (€/farm) & 218907 & 124635 & & \\
\hline & & Variable costs ( $€ /$ year) & 22180 & 13233 & & 411.81 \\
\hline & & Hectares & 41.91 & 22.84 & & \\
\hline \multirow[t]{5}{*}{ C1-C4 } & 594 & Market return (€/year) & 14489 & 12354 & & \\
\hline & & Labour (hours/year) & 1176 & 675 & 12.32 & \\
\hline & & Capital (€/farm) & 163472 & 97321 & & \\
\hline & & Variable costs ( $€ /$ year) & 19521 & 13371 & & 394.70 \\
\hline & & Hectares & 36.71 & 24.24 & & \\
\hline
\end{tabular}

${ }^{a}$ Market return (€/year) / labour input (hour/year)

${ }^{\mathrm{b}}$ Market return (€/year) / hectares

As the tables reveal, partial productivities show a continuous increase in relation to increasing farm size. From the econometric point of view, however, large rotation within size classes hinders the estimation of separate production functions for different size classes. The differences between size classes are derived from the joint production function when farm specific elasticities and returns to scale are calculated.

It is also of interest to determine whether the development of productivity differs among subsidy areas. Table 3 presents the main statistics according to the subsidy area. The average land area of grain farms decreases as we move from subsidy area A to area B and from B to C. The standard deviation is also somewhat smaller in subsidy area $\mathrm{C}$ than in other areas.

The number of labour hours also decreases from subsidy area A to area B and from B to C. However, market returns do not decrease at the same rate as labour hours. Partial productivity for labour is highest in southern Finland, but at the same lower level in areas B and C. The results indicate regional differences in climate, field plot structure, soil type and other factors.

Farms are fixed to their subsidy area. This means that it is technically possible to estimate separate production functions for subsidy areas. The differences in the specification of production functions between subsidy regions will therefore be tested.

\section{Results}

\section{Tests for model specifications}

As a starting point, we assume flexible translog production functions presented in equations 3 and 4. In addition, we allow the rate of technical change to differ between farm size classes, either in the form of different time trends or time dummies. We apply the F-test between restricted and unrestricted models in order to analyze whether a simpler model 
Vol. 18 (2009): 283-301.

Table 4. Specification tests for the time trend model.

\begin{tabular}{lcccc}
\hline Hypothesis & F-test value & Critical value & Risk level & Degrees of freedom \\
\hline$H_{0}: \alpha_{D_{f}}=0$ & 6.02 & 1.90 & $<0.001$ & 404,2854 \\
$H_{0}: \alpha_{j k}=0$ & 3.59 & 3.14 & $<0.005$ & 6,2854 \\
$H_{0}: \alpha_{t}=\alpha_{t t}=\alpha_{j t}=\alpha_{D_{s c t}=0}$ & 36.06 & $\sim 3.00$ & $<0.001$ & 11,2854 \\
$H_{0}: \alpha_{D_{s c t}}=0$ & 8.01 & 4.69 & $<0.001$ & 4,2854 \\
$H_{0}: \alpha_{D_{t, e}}=\alpha_{D_{t, C A P}}=0$ & 68.59 & 4.18 & $<0.001$ & 5,2854 \\
$H_{0}: \alpha_{j k}=\alpha_{t}=\alpha_{t t}=\alpha_{j t}=\alpha_{D_{s c t}}=0$ & 24.68 & 2.33 & $<0.001$ & 20,2854
\end{tabular}

$D_{f i}$ are farm dummies.

$D_{s c}$ are size class dummies.

$D_{t, e}$ are dummies for exceptional years 1987, 1989, 2000.

$D_{t, C A P}$ are dummies for CAP years.

provides a sufficient description for the relationship in the data. The test procedure is the following:

$F=\frac{\left(\mathrm{RSS}_{\mathrm{R}}-\mathrm{RSS}_{U}\right) / \mathrm{m}}{\mathrm{RSS}_{U} /(\mathrm{n}-\mathrm{k})}$,

where RSS refers to restricted (R) and unrestricted (U) residual sum of squared errors, $n$ is the number of observations, $\mathrm{k}$ the number of regressors and $m$ the number of restrictions (Hsiao, 2003). This allows us to test the statistical significance of differences between models. We initially tested whether an ordinary least squares model performs better than a least squares dummy variable (fixed effect) model. The F-test (Table 4) indicates that the fixed effect model should be applied.

When functional form of the production function was tested it turned out that the Cobb-Douglas without time components is not sufficient to describe the relationship between the output and inputs. Thus, significant technical change occurs over time $(p<0.001)$. Technical change also differs statistically significantly between farm size classes $(p<0.001)$. Cross terms of inputs and their second order terms are significant at the $0.5 \%$ risk level. In addition, although the first derivatives of all inputs are positive (monotonicity is satisfied), the production function including the above-mentioned terms violates the regularity condition for most of the data points, according to the principal minor test. Therefore, these terms have been removed from the model specification that the empirical results are based on. The final function form for the production function is logarithmic production function, which is not as flexible as translog, but more flexible than Cobb-Douglas. For this on we call this function as extended Cobb-Douglas.

The CAP dummy variables were also tested for the TT model and were found significant $(p<$ $0.001)$. The same concerns annual dummies capturing exceptionally good or poor weather conditions. Subsidy areas were also found significant as interaction terms with capital ( $p<0.001)$. Therefore, subsidy-area-specific production functions were also estimated. However, to save space, only the results based on the joint production function of all subsidy areas are presented in the appendices. ${ }^{11}$ This is because the TFP trends were found to follow the same pattern in all subsidy areas (see Fig. 2).

\section{Elasticities and technical change}

Output elasticities with respect to variable inputs are calculated from $\varepsilon_{q}=\partial \ln y / \ln x_{j}$. The input elasticities vary over time but not across farms. These variations result from the use of an extended Cobb-Douglas

11 Subsidy-area-specific production functions are available from the authors on request. 


\section{AGRICULTURAL AND FOOD SCIENCE}

\section{Myyrä, S. et al. Productivity growth on Finnish grain farms}

function. Returns to scale are calculated from the sum of the input elasticities.

The results indicate that output elasticities for labour are quite low. On average, elasticity for labour has been around $0.10-0.11$. Over the years the investments in buildings, machinery and land improvements have given a larger contribution to the output. Independent of the model, elasticities for capital were around $0.26-0.28$, and were found to be invariant over time.

The farm-specific estimates of returns to scale (RTS) are defined as the elasticity of output with regard to a proportionate change in all inputs. Sample means of returns to scale were 0.79 (TT) and 0.77 (GI). Means of RTS were found to be below one, indicating decreasing returns to scale at the average level. ${ }^{12}$

The results indicate no major differences in elasticities or returns to scale between subsidy areas. This also holds over the entire study period. There are cross-term parameters between time and input variables in production functions, which allow technical changes to be farm-specific.

The dummy variable indicating the policy regime change from national agricultural policy to the CAP was found negative and significant in the TT model (Appendix 2). In the TT model, the shift of the production function is smooth. However, the rate of technical change slowed down after the mid1990s, signalling the changes in production structure and agricultural policy. The structural change resulted in one third (750 000 ha) of Finnish arable land being transferred to cultivation under land tenure arrangements. It has also been shown that land improvements are not carried out as well on tenure farmed plots as on owned plots (Myyrä et al. 2005). Neglect of land improvements might even lead to technical regress. Technical regress might also be due to the environmental regulations set in environmental programmes. Such regulations limit the use of fertilizers and pesticides and require some parts of fields to be left out of production. Buffer

12 The results based the standard OLS model suggest that returns to scale are close to constant. This indicates that productivity levels differ between farms, but when this difference is taken into account, returns to scale do not support productivity growth with increasing size of the farm. zones and strips beside waterways are examples of this. The results signal that grain farming in Finland may be in danger of being caught in the low productivity trap, where farmers lack incentives to improve productivity.

The GI model captures the annual variation in the production function caused by changing weather conditions from year to year. The exceptional cropping years can be easily distinguished (Table 5). The large variation in technical change highlights the nature of crop farming in Finland. The change in productivity, which is mainly caused by technical change, is strongly related to the weather conditions. Based on these findings, we argue that it might be misleading to rely on statements of productivity changes in Finnish crop production based on short time series. One extension is that the production function estimated from a very short data set might give biased results, simply because of the weather conditions.

The general index reveals the annual variation in technical change. The overall mean of technical change was 0.011 and the standard deviation was as large as 0.171 . This result indicates that is not easy to verify slow technical process if the production function typically shifts with a $95 \%$ confidence interval by $\pm 34 \%$ annually. Other industries do not suffer from similar fluctuation, but there are numerous examples of the connection between technical change in grain production and the weather (Zhang 1996).

\section{Total factor productivity growth}

Total factor productivity (TFP) increased by $0.6 \%$ per year in the GI model and $1.7 \%$ per year in the TT model. However, the resulting change in TFP in the TT model over the study period was at the same level than the highest yearly changes in TFP measured by the GI model. The results for the annual changes in total factor productivity are presented in Figure 2.

Figure 2 illustrates the idea of using two separate models. The annual variation in TFP is large and captured by the general index model, because 
Vol. 18 (2009): 283-301.

Table 5. Means of input elasticities, returns to scale and technical change.

\begin{tabular}{lcccc}
\hline & \multicolumn{3}{c}{ Elasticities } \\
Model / farm size /subsidy area & Labour & Capital & Variable cost & RTS \\
\hline Time trend (TT) & 0.106 & 0.282 & 0.403 & 0.791 \\
General index (GI) & 0.098 & 0.264 & 0.406 & 0.768 \\
\hline \multicolumn{2}{c}{ Technical change } \\
very small & TT & GI \\
\cline { 2 - 4 } small & 0.010 & -0.001 \\
medium & 0.013 & 0.009 \\
large & 0.017 & 0.012 \\
very large & 0.021 & 0.015 \\
A & 0.023 & 0.019 \\
B & 0.018 & 0.007 \\
C1-C4 & 0.016 & 0.010 \\
\hline
\end{tabular}

this model allows more flexibility with respect to year-to-year changes in productivity. However, it might be impossible to capture the general trend in TFP based only on general index model results. This issue was topical during the first years of EU membership, when the CAP was implemented in Finland. As Figure 2 illustrates, the cropping year 1994 was above the average. However, during the following years from 1995 to 1999, the first under the CAP, weather conditions were poor and TFP collapsed. At that time, it would have been impossible to say anything about the contribution of the policy regime change to the productivity of grain farming in Finland only based on the general index model. Thus, we used in our time trend model a CAP dummy that allows the time trend to differ before and after the EU accession. Estimation results (see Appendix 2) give empirical justification that the CAP has hindered the increase in the productivity of grain farming in Finland. However, the size of the effect is extremely small.

The productivity trends of different subsidy areas were also examined, as we found that production functions differed between subsidy areas.
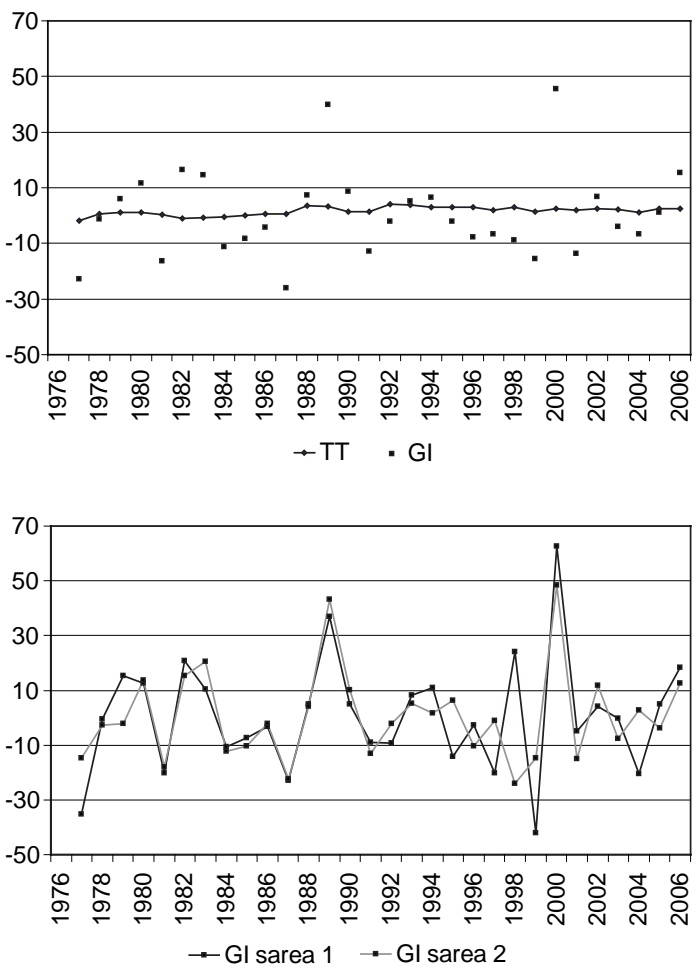

Fig. 2. Annual change in total factor productivity. TT = Time trend. GI = General index. Sarea 1 refers to subsidy area A and sarea 2 to subsidy area B. 
Myyrä, S. et al. Productivity growth on Finnish grain farms

Thus, the data were divided according to subsidy area and the same models were applied ${ }^{13}$ for each region. The trends in total factor productivity are presented in the lower parts of Figure 2. The results indicate that productivity trends for the most part follow the same pattern. ${ }^{14}$ Some exceptional years were 1995, 1997, 1998 and 2004, all which were under the CAP.

\section{Conclusions}

In this paper we applied an extended Cobb-Douglas production function production function with both time trend and general index specifications to estimate TFP growth on grain farms. We also decomposed TFP growth into technical change and the scale effect. For long-term development, the time-trend model suggests faster TFP growth: the annual growth rate calculated from sample means indicates $1.7 \%$ annual growth for the TT model and $0.6 \%$ for the GI model. Of course, over the long term this difference implies a considerable productivity gap. However, comparison of the models is difficult because of their radical differences in capturing annual variation in TFP. The annual variation in TFP growth is large in the GI model, because it allows more flexibility with respect to year-to-year changes in productivity. This variation is mainly caused by the variability in yields. The results suggest that in agriculture, and especially in grain farming, it is difficult to evaluate, for example, the short term effects of policies on technical change. The results indicate that it might be misleading to rely on reports concerning productivity changes in Finnish crop production that are based on short time series. The selection of the first research year is also always a problem in the analysis of productivity changes in crop production. We addressed these challenges by taking a long (30 years) time

13 Area-specific models are available from the authors on request.

14 The number of observations was insufficient for regional estimation of the GI model in subsidy area 3. series of data for Finnish grain farms, in which were helped by the reliable and well-established Finnish bookkeeping system. Based on our experience, the time trend model is not flexible enough to capture the annual variation in Finnish grain farming, and in this sense results gained from the general index model are preferable. Baltagi and Griffin (1988) also preferred the GI model, since it closely follows the changes in Divisia indices. Kumbhakar et al. (1999), however, presented some contradictory views on the TT model.

Technical change was the main contributor to productivity growth in our analysis. The scale had only a moderate effect and for the whole period the effect was close to zero, although in some periods its effect was considerable. It is important to note that the scale effect can contribute to productivity even when decreasing returns to scale prevail. This takes place when the aggregate input use diminishes (Kumbhakar and Lovell 2000). TFP growth on the sample farms continued to be relatively stable both before and after EU accession. The slow development may partially be related to the fact that many farmers have ceased animal production but may still continue arable farming. However, the full scale of this phenomenon is not captured in the bookkeeping data. Further studies on the consequences of structural development for the growth in total factor productivity are certainly needed, because all current studies have focused on a particular production line or industry but not on the structural change in production lines within the industry.

We conclude that there is no single average production function that alone could explain the variety of developments in crop production. Crop production differs from other industries because of the strong links between weather conditions and yields. It is possible to make only minor adjustments to input use during the growing season. This causes input use to be almost equal from one year to the next, even though the yield varies. Thus, optimization of inputs is a discrete choice at certain points of the crop lifecycle and not available at every stage of the production process. Both variability in the outcomes and the underlying trends could be best revealed by using a variety of meth- 
Vol. 18 (2009): 283-301.

ods, including those that are flexible enough to describe annual variation.

The productivity of Finnish grain farming has increased over the long term. However, this development has not been rapid enough to cover unfavourable development in the output-input price relation and sustain the profitability of grain farms (Taloustohtori 2009). In the triune of farm profitability, including prices, subsidies and productivity, it is not productivity that has broken down, even though this has been a very popular topic in the media. However, a more rapid increase in productivity would have helped in achieving profitability goals. The decreasing effects from the recent policy changes, namely the introduction of the CAP, on TFP are worrying with respect to the future of Finnish grain farming.

The result gained from the general index model also raises some environmental and economic questions. First, does runoff fluctuate annually in a reverse manner to technical change? Second, what are the possible actions of the farmer if the worst weather conditions occur when costs and subsidies are high and output prices are low? Are current fertilization norms overoptimistic when counting on favourable weather conditions?

Thirtle et al. (2004) listed possible reasons for biases in productivity growth studies. They mentioned, for example, that conventional measures of TFP do not take into account inputs and outputs that are external to the production process. This is true in almost all studies of productivity changes in agriculture and also in our analysis. Over $90 \%$ of all grain farmers take part in environmental programmes and are paid for their participation. This means that almost all grain farmers face inputs and outputs from environmental programmes. However, environmental outputs such as buffer zones are not taken into account in our aggregate output measure. This is clearly one way to improve the empirical analysis.

Thirtle et al. (2004) also mentioned that it is difficult to take into account quality changes in inputs and outputs. We used general price indexes to adjust quantities. This means that we obtain biased estimates of quantities if the quality development of outputs or inputs in our data differs from the general development. The pricing of outputs in the market is adjusted for the average quality of crops. It would be interesting to identify the determinants of output quality, and to model and quantify their individual factor impacts.

\section{References}

Baltagi, B.H. \& Griffin, J.M. 1988. A general index of technical change. Journal of Political Economy 96: 20-41.

Bauer, B.W. 1990 Decomposing TFP growth in the presence of cost inefficiency, non-constant returns to scale, and technological progress. Journal of Productivity Analysis 1: 287-299.

Coell, T.J., Rao P.D.S. and Battese, G.E. 1998. An Introduction on Efficiency and Productivity Analysis. Kluwer Academic Publishers. $275 \mathrm{p}$.

Denny, M., Fuss, M. and Waverman, L. 1981. The measurement and interpretation of total factor productivity in regulated industries with an application to Canadian telecommunications. In: Cowing, T.G. and Stevenson, R.E. (eds.) Productivity measurement in regulated industries. New York. Academic Press. p. 179-218.

FADN 2009.. Farm Account Data Network.Cited Marsh 2009. Updated Marsh 2009Available on the Internet: https://portal.mtt.fi/portal/page/portal/www_en/ Research/Economics/Business\%20Accounting.

Gravelle H. \& Rees R. 1989. Microeconomics. 2nd ed. Longman Group UK Limited

Hemilä, K. 1982 Measuring technological change in agriculture: An application based on the CES production function. Journal of the Scientific Agricultural Society of Finland 54: 165-223.

Heshmati, A. \& Kumbhakar, S.C. 1994. Farm heterogeneity and technical efficiency: Some results from Swedish dairy farms. Journal of Productivity Analysis 5: 45-61.

Hsiao, C. 2003. Analysis of Panel Data. Second Edition. Econometric Society Monographs 34, Cambridge University Press. $366 \mathrm{p}$.

Ihamuotila, R. 1972. Productivity and the aggregate production function in the Finnish agricultural sector, 1950-1969. Working paper of Agricultural Economics Research Institute of Finland 25.

Iltanen S. 1999. Land leasing and land rents on Finnish bookkeeping farms. Working paper of Agricultural Economics Research Institute of Finland 13/1999.

Kumbhakar S.C.. Heshmati A. \& Hjalmarsson L. 1999. Parametric Approaches to Productivity Measurement: A Comparison among Alternative Models. Scandinavian Journal of Economics 101: 405-424.

Kumbhakar S.C. \& Lovell C.A. 2000. Stochastic Frontier Analysis. Cambridge University Press.

Liu, X. \& K. Pietola, 2005. Forward hedging under price and production risk of wheat. Agricultural and Food Science 14: 123-133.

Myyrä S. 2004. Productivity development in agriculture. 
Myyrä, S. et al. Productivity growth on Finnish grain farms

In: Niemi. J. \& Ahlstedt. J. (eds.). Finnish Agriculture and Rural industries. Agrifood Research Finland Publications 104b.

Myyrä, S., Ketoja, E., Yli-Halla, M. \& Pietola, K. 2005. Land improvements under land tenure insecurity : the case of $\mathrm{pH}$ and phosphate in Finland. Land Economics 81: 557-569.

Myyrä, S. \& Pietola, K. 1999. Tuottavuuskehitys Suomen maataloudessa 1987-97. Maatalouden taloudellinen tutkimuslaitos (MTTL). Tutkimuksia 234. $57 \mathrm{p}$.

Nauges, C., Koundour, P., Laukkanen, M. \& Myyrä, S. 2009. EU agricultural policy change: Effects on farmers' risk attitudes. European Review of Agricultural Economics 36: 53-77.

Niemi. J. \& Ahlstedt. J. 2004. Finnish agriculture and rural industries. Agrifood Research Finland. Publications 103.

Olley, S. \& Pakes, A. The dynamics of productivity in the telecommunication equipment industry. Econometrica 64: 1263-1297.

Riepponen, L. 2003. Maidon ja viljan tuotantokustannukset Suomen kirjanpitotiloilla vuosina 1998-2000 (in Finnish). Maa- ja elintarviketalous 19: $32 \mathrm{~s}$.

Ryhänen, M. 1994. Input substitution and technological development on Finnish dairy farms for 1965-1991. Agricultural Science in Finland 3: 525-599.

Sims, E. 1994. The rate of technical change in Finnish agriculture, 1960-1990. Agricultural Science in Finland 3: 151-160.

Sipiläinen, T. 2003. Suurten maito- ja viljatilojen suoritusky- ky ja sen kehittäminen. Performance of large dairy and cereal farms and its development. Helsingin yliopisto, Taloustieteen laitos, Julkaisuja 38. 90 p.

Sipiläinen, T. \& Ryhänen, M. 2005. Technical change in Finnish grass silage production. Agricultural and Food Science 14: 250-263.

Sipiläinen, T. 2007 Sources of productivity growth on Finnish dairy farms: application of an input distance function. Acta Agriculturae Scandinavica Section C. Food Economics 4: 65-76.

Sipiläinen, T. 2008. Components of productivity growth in Finnish agriculture. Agrifood Research Finland, Reports 116: $154 \mathrm{p}$.

Taloustohtori 2009. Web based tool for monitoring the profitability of agricultural enterprises in Finland. Cited Marsh 2009. Updated Marsh 2009. Available on the Internet: https://portal.mtt.fi/portal/page/portal/economydoctor/farm_economy.

Thirtle, C., Lin, L. \& Holding, J. 2004. Explaining the decline in UK agricultural productivity growth. Journal of Agricultural Economics 55: $343-366$.

TIKE 2006. Yearbook of Farm Statistics 2005. Information Centre of the Ministry of Agriculture and Forestry, TIKE. Helsinki. $268 \mathrm{p}$.

Zhang, B. 1997. Total Factor Productivity in the Former Soviet Union. Journal of Comparative Economics 24: 202-209

Ylätalo, M. 1987 Maatalouden tuottavuus ja investoinnit (in Finnish). Pellervon taloudellisen tutkimuslaitoksen julkaisuja 8.

\title{
SELOSTE
}

\section{Viljatilojen tuottavuuskehitys vuosina 1976-2006}

\author{
Sami Myyrä, Pekka Pihamaa ja Timo Sipiläinen \\ МТT ја МMM
}

Maatalouden tuottavuus ja erityisesti tuottavuuden nousu ovat välttämättömiä edellytyksiä suomalaisten maatilojen ja elintarviketeollisuuden selviytymiselle. Epäsuotuisat olosuhteet ja pieni tilakoko ovat jo sinänsä haasteita, mutta tuottavuuskehityshaaste on entisestään koventunut, kun tuet on irrotettu tuotannosta. Lisäksi viljelijöiden kannusteet tuottavuuskehityksen nopeuttamiseen ovat olennaisesti heikentyneet pellon omistusrakenteessa tapahtuneen muutoksen myötä. Vuonna 2004 vain puolet peltoalasta oli viljelijöiden omistuksessa.

Suomalaisten viljatilojen tuottavuuskehitys johtuu pitkälti teknologisesta kehityksestä. Tutkimuksen mukaan skaalavaikutukset, eli suurtuotannon edut, ovat tarkasteluvälillä vaikuttaneet hyvin vähän tuottavuuskehitykseen, ja lisäksi niiden vaikutus on ollut ajan myötä jopa laskeva.

Vuosina 1976-2006 viljatilojen tuottavuus nousi mittaustavasta riippuen keskimäärin 0,6-1,7 \% vuodessa. Keskimääräinen vuotuinen tuottavuuskehitys oli kuitenkin niin pieni, että kokonaiskehitys koko tarkastelujaksolla oli samansuuruinen kuin suurimmat vuotuiset vaihtelut. Tulos osoittaa viljanviljelyn tuottavuuden olevan sidoksissa vuosittain vaihteleviin sääolosuhteisiin. Tämä haastaa tutkimusmenetelmät, joiden pitäisi toisaalta osoittaa hidas taustalla oleva tuottavuuskehitys ja samalla suuri vuotuinen vaihtelu tuottavuuden tasossa. 
Vol. 18 (2009): 283-301.

\section{Appendix}

Appendix 1.

Table 1. The consumer price index (Inflation), the price index for grain (Grain) and the input price index (Input). Source: Statistics Finland.

\begin{tabular}{|c|c|c|c|c|c|c|c|}
\hline Year & Inflation & Grain & Input & Year & Inflation & Grain & Input \\
\hline 1976 & 29.9 & 107.8 & 45.0 & 1995 & 92.6 & 101.9 & 94.6 \\
\hline 1977 & 33.7 & 115.8 & 51.7 & 1996 & 93.1 & 104.6 & 96.4 \\
\hline 1978 & 36.2 & 122.4 & 53.9 & 1997 & 94.3 & 101.4 & 98.4 \\
\hline 1979 & 38.8 & 129.8 & 57.5 & 1998 & 95.6 & 98.4 & 96.4 \\
\hline 1980 & 43.4 & 158.5 & 64.5 & 1999 & 96.7 & 97.5 & 94.2 \\
\hline 1981 & 48.6 & 188.5 & 78.1 & 2000 & 100.0 & 100.0 & 100.0 \\
\hline 1982 & 53.1 & 229.8 & 85.9 & 2001 & 102.5 & 94.2 & 101.8 \\
\hline 1983 & 57.6 & 234.7 & 93.7 & 2002 & 104.1 & 91.3 & 101.5 \\
\hline 1984 & 61.6 & 249.8 & 102.4 & 2003 & 105.1 & 87.2 & 102.5 \\
\hline 1985 & 65.3 & 273.3 & 107.9 & 2004 & 105.3 & 84.7 & 105.1 \\
\hline 1986 & 67.6 & 286.1 & 102.8 & 2005 & 106.2 & 79.7 & 108.2 \\
\hline 1987 & 70.1 & 294.6 & 101.4 & 2006 & 108.1 & 87.3 & 113.7 \\
\hline 1988 & 73.6 & 297.3 & 100.4 & & & & \\
\hline 1989 & 78.4 & 292.1 & 104.7 & & & & \\
\hline 1990 & 83.1 & 283.6 & 113.2 & & & & \\
\hline 1991 & 86.6 & 253.7 & 119.4 & & & & \\
\hline 1992 & 88.8 & 248.2 & 122.0 & & & & \\
\hline 1993 & 90.7 & 255.0 & 123.8 & & & & \\
\hline 1994 & 91.7 & 239.5 & 121.2 & & & & \\
\hline
\end{tabular}


Myyrä, S. et al. Productivity growth on Finnish grain farms

Appendix 2. Estimated production functions.

Time trend model:

\begin{tabular}{|c|c|c|c|c|}
\hline \multirow[b]{2}{*}{ Parameter } & \multicolumn{3}{|c|}{ Parameter Estimates } & \multirow[b]{2}{*}{$\operatorname{Pr}>|t|$} \\
\hline & Estimate & Std Err & t Value & \\
\hline Intercept & 0.917713 & 0.4335 & 2.12 & 0.0343 \\
\hline CAP dummy & -0.00187 & 0.00483 & -0.39 & 0.6982 \\
\hline CAP dummy^2 & -0.00108 & 0.000479 & -2.25 & 0.0243 \\
\hline d 1989 & 0.101015 & 0.0235 & 4.30 & $<.0001$ \\
\hline d 1987 & -0.29597 & 0.0252 & -11.76 & $<.0001$ \\
\hline d 2000 & 0.187878 & 0.0275 & 6.84 & $<.0001$ \\
\hline $\mathrm{l}\left(\mathrm{x}_{\mathrm{j}}\right)$ & 0.102927 & 0.0314 & 3.28 & 0.0011 \\
\hline$c\left(x_{j}\right)$ & 0.311363 & 0.0471 & 6.61 & $<.0001$ \\
\hline $\operatorname{cd}\left(\mathrm{x}_{\mathrm{j}}\right)$ & 0.36096 & 0.0384 & 9.41 & $<.0001$ \\
\hline $\mathrm{t}$ & -0.02389 & 0.0217 & -1.10 & 0.2715 \\
\hline lt $\left(\mathrm{x}_{\mathrm{j}} \mathrm{t}\right)$ & 0.00021 & 0.00160 & 0.13 & 0.8954 \\
\hline $\operatorname{ct}\left(\mathrm{x}_{\mathrm{j}} \mathrm{t}\right)$ & -0.00178 & 0.00232 & -0.77 & 0.4441 \\
\hline $\operatorname{cdt}\left(\mathrm{x}_{\mathrm{j}} \mathrm{t}\right)$ & 0.002529 & 0.00208 & 1.22 & 0.2239 \\
\hline tt & 0.002373 & 0.000478 & 4.97 & $<.0001$ \\
\hline $\mathrm{d} 2\left(\mathrm{~d}_{2} \mathrm{t}\right)$ & 0.003373 & 0.00135 & 2.50 & 0.0125 \\
\hline $\mathrm{d} 3\left(\mathrm{~d}_{3} \mathrm{t}\right)$ & 0.006766 & 0.00170 & 3.98 & $<.0001$ \\
\hline $\mathrm{d} 4\left(\mathrm{~d}_{4} \mathrm{t}\right)$ & 0.010479 & 0.00199 & 5.26 & $<.0001$ \\
\hline $\mathrm{d} 5\left(\mathrm{~d}_{5} \mathrm{t}\right)$ & 0.01304 & 0.00238 & 5.47 & $<.0001$ \\
\hline
\end{tabular}

$1=$ labour, $\mathrm{c}=$ capital, $\mathrm{cd}=$ variable cost $\mathrm{t}=$ time and $\mathrm{d} 1 \ldots \mathrm{d} 5$ are farm size class dummies. The model includes 404 fixed effect dummies separately for each farm (405) which are not presented here.

\begin{tabular}{lccccccc}
\hline Equation & DF Model & DF Error & SSE & MSE & Root MSE & R-Square & Adj R-Sq \\
\hline y & 422 & 2856 & 185.6 & 0.0650 & 0.2549 & 0.9006 & 0.8860 \\
\hline
\end{tabular}


Vol. 18 (2009): 283-301.

General index model

\begin{tabular}{|c|c|c|c|c|}
\hline Parameter & $\begin{array}{c}\text { Parameter } \\
\text { Estimate }\end{array}$ & $\begin{array}{c}\text { Standard } \\
\text { Error }\end{array}$ & t Value & $\operatorname{Pr}>|t|$ \\
\hline Intercept & 1.20601 & 0.51996 & 2.32 & 0.0204 \\
\hline $\mathrm{l}\left(\mathrm{x}_{\mathrm{j}}\right)$ & 0.10530 & 0.02965 & 3.55 & 0.0004 \\
\hline$c\left(x_{j}\right)$ & 0.24785 & 0.04878 & 5.08 & $<.0001$ \\
\hline $\operatorname{cd}\left(x_{j}\right)$ & 0.41726 & 0.03703 & 11.27 & $<.0001$ \\
\hline lt $\left(x_{j} t\right)$ & -0.00042803 & 0.00150 & -0.29 & 0.7756 \\
\hline $\mathrm{ct}\left(\mathrm{x}_{\mathrm{j}} \mathrm{t}\right)$ & 0.00095802 & 0.00235 & 0.41 & 0.6834 \\
\hline $\operatorname{cdt}\left(\mathrm{x}_{\mathrm{i}} \mathrm{t}\right)$ & -0.00065930 & 0.00199 & -0.33 & 0.7407 \\
\hline
\end{tabular}

There are also 5 (size class) $\times 29$ (year) +405 (farm) $=550$ dummy variables in the general index model, which are not presented here.

$\mathrm{l}$ = labour, $\mathrm{c}=$ capital, $\mathrm{cd}=$ variable cost, $\mathrm{t}=$ time.

\begin{tabular}{lccccccc}
\hline Equation & DF Model & DF Error & SSE & MSE & Root MSE & R-Square & Adj R-Sq \\
\hline $\mathrm{y}$ & 561 & 2717 & 144.1 & 0.0530 & 0.2303 & 0.9229 & 0.9070 \\
\hline
\end{tabular}

